\title{
ДОСЛІДЖЕННЯ СУЧАСНОГО СТАНУ ТА АНАЛІЗ ДЕРЖАВНОГО БОРГУ УКРАЇНИ
}

\section{STUDY OF THE CURRENT SITUATION AND ANALYSIS OF THE STATE DEBT OF UKRAINE}

\author{
Романькова Оксана Миколаївна \\ кандидат хімічних наук, доцент, \\ Донбаська державна машинобудівна академія, м. Краматорськ \\ ORCID: https://orcid.org/0000-0002-3698-0560 \\ Romankova Oksana \\ Donbass State Engineering Academy, Kramatorsk
}

\begin{abstract}
У статті розглянуто державний та гарантований державою борг України, його структуру, помісячні платежі за державним боргом у 2021 році. На основі даних Міністерства фрінансів України досліджено динаміку державного й гарантованого державою боргу України за період 2009-2021 рр., проведено аналіз. Від способів врегулювання боргової проблеми залежить рівень бюджетного забезпечення держави, стабільність її національної валюти, а, звідси, фрінансова підтримка міжнародних фрінансових організацій. Необхідні пошуки нових шляхів вдосконалення механізмів управління та обслуговування державного боргу країни, посилення адміністративного контролю за фрінансовими потоками з боку держави, використання найкращих світових практик, а також залучення іноземних інвесторів, що створить в майбутньому сприятливий інвестиційний клімат.

Ключові слова: державний борг, зовнішній державний борг, внутрішній державний борг, гарантований державний борг, структура.
\end{abstract}

В статье рассмотрен государственный и гарантированный государством долг Украины, его структура, ежемесячные платежи государственного долга в 2021 году. На основе данных Министерства фринансов Украины исследована динамика государственного и гарантированного государством долга Украины за период 20092021 гг., проведен анализ. От способов урегулирования долговой проблемы зависит уровень бюджетного обеспечения государства, стабильность ее национальной валюты, а также, финансовая поддержка международных фринансовых организаций. Необходимы поиски новых путей усовершенствования механизмов управления и обслуживания государственного долга страны, усиление административного контроля за фринансовыми потоками со стороны государства, использование лучших мировых практик, а также привлечение иностранных инвесторов, что создаст в будущем благоприятный инвестиционный климат.

Ключевые слова: государственный долг, внешний государственный долг, внутренний государственный долг, гарантированный государственный долг, структура.

The article considers the state and state-guaranteed debt of Ukraine, its structure, monthly payments on the state debt in 2021. Based on the data of the Ministry of Finance of Ukraine, the dynamics of public and state-guaranteed debt of Ukraine for the period 2009-2021 is studied, the analysis is carried out. Public debt - the total amount of debt obligations of the state to repay received and outstanding loans (borrowings) as of the reporting date, arising from government borrowing. State-guaranteed debt - the total amount of debt obligations of business entities - residents of Ukraine to repay received and outstanding as of the reporting date loans (loans), the implementation of which is secured by state guarantees. In Ukraine, public debt is a total debt obligations to other countries, international economic organizations, others, as well as owners of government securities and other creditors of our country. Unfortunately, the modern economy of the state is in debt and beyond the capabilities of the country, and this creates the need to reduce the expenditure of the budget for investment and social purposes, as well as purposes that are not related to the payment and servicing of public debt. Monetary, budgetary and debt policies of the country interact very closely with each other: public debt affects economic growth, cash flow, inflation, refinancing rate, unemployment rate, investment in the economy as a whole and in certain sectors of the economy, and affects the reduction investment resources in the economy and the destruction of reproductive processes, the decline of economic development. The level of budget support of the state, the stability of its national currency, and, hence, the financial support of international financial organizations, depends on the ways of resolving the debt problem. It is necessary 
to find ways to improve the mechanisms of management and servicing of the country's public debt, strengthening administrative control over financial flows by the state, use of world best practices, as well as attracting foreign investors, which will create a favorable investment climate in the future.

Keywords: public debt, external public debt, domestic public debt, guaranteed public debt, structure.

Постановка проблеми. Аналіз сучасного стану державного боргу України $€$ актуальним тому, що проблема обслуговування державного боргу - один 3 ключових чинників стабільності країни. Процес державних внутрішніх та зовнішніх запозичень завжди був пов'язаний з державним бюджетом країни. На сучасному етапі Україна переживає політичну, фрінансово-економічну й банківську кризу. Військовий конфрлікт на сході України разом 3 присутніми макроекономічними дисбалансами зруйнували макрофрінансову стабільність держави. Економіка України, в цілому, сьогодні переживає вкрай складний період і вимагає невідкладних перетворень. У зв'язку з цим ефективне управління державним боргом $€$ вирішальним та актуальним для стабілізації економіки.

Аналіз останніх досліджень і публікацій. Вагомий внесок у дослідження питань стосовно державного боргу внесли як зарубіжні, так й українські вчені-економісти, а саме: Дж. Кейнс, М. Фрідман, А. Сміт, О.Д. Василик, В.О. Суторміна, К.П. Павлюк, А.С. Гальчинський та інші.

Метою роботи $€$ дослідження сучасного стану, структури державного й гарантованого державою боргу України та їх аналіз.

Виклад основного матеріалу. Державний борг - загальна сума боргових зобов'язань держави 3 повернення отриманих та непогашених кредитів (позик) станом на звітну дату, що виникають внаслідок державного запозичення [1]. В Україні державний борг являє собою сукупні боргові зобов'язання як перед державами інших країн, міжнародними економічними організаціями, іншими особами, так й власниками державних цінних паперів та іншими кредиторами нашої країни. Державний борг поділяють на зовнішній та внутрішній, причому оцінка зовнішнього боргу проводиться в іноземній валюті, саме, в доларах США, а внутрішнього тільки у національній валюті.

На жаль, сучасна економіка держави носить борговий характер та виходить за рамки можливостей країни, і це породжує необхідність в скороченні видаткової частини бюджету на інвестиційні та соціальні цілі, а так само цілі, які не пов'язані 3 оплатою і обслуговуванням державного боргу. Валютна, бюджетна і бор- гова політика країни дуже тісно взаємодіють один з одним: державний борг впливає на економічне зростання, грошовий потік, інорляцію, ставку рефрінансування, рівень безробіття, інвестиційний обсяг в економіку держави в цілому і в певні сектори економіки, а також впливає на скорочення інвестиційних ресурсів в економіці й руйнування у відтворювальних процесах, спад економічного розвитку.

Високе зростання державного боргу тягне за собою загрозу для безпеки економіки країни і стійкості бюджетної системи. Неаргументована грошово-кредитна, курсова та бюджетна політика держави викликає занепокоєння на фрінансовому ринку по відношенню до інвестиційного клімату, і спонукає інвесторів висувати вимоги для підвищення преміювання за ризик. Це в основному відноситься до країн, які розвивають і фрормують ринки цінних паперів, в яких кредитори мають право відмовитися від прийняття довгострокових зобов'язань, а це може негативно вплинути на фрормування фрінансового ринку та економічне зростання.

Країни 3 низьким кредитним рейтингом змушені широко надавати державні гарантії приватним національним позичальникам, обтяжуючи тим самим державний бюджет у разі їх неплатоспроможності. У структурі зовнішнього боргу таких країн частка приватного негарантованого державою боргу відносно низька. У країнах, що розвиваються і з ринками, що фрормуються, велика частина зовнішніх боргових зобов'язань припадає на державний та гарантований державою борг, в розвинених країнах переважають борги приватного сектора перед нерезидентами.

Кредитні рейтинги України покращувалися з моменту реструктуризації державного боргу в 2015 році. Відтоді усі чотири міжнародні кредитні рейтингові агентства підняли рейтинг України на 2-3 позиції. Останнє підвищення кредитного рейтингу України відбулось у грудні 2018 р., коли рейтингове агентство Moody's підвищило рейтинг з Сaа2 до Caa1. Підвищенню кредитного рейтингу України сприяли, зокрема, угода між Україною та МВФ щодо нової програми фрінансування Stand-by, позитивні очікування щодо зниження рівня корупції в Україні на фроні впроваджених реформ 
та посилення економічної стійкості України на фоноі наявних геополітичних ризиків [2].

Сьогодні в Україні реально склалася ситуація, коли відносини в ссрері державного боргу перетворюються і розвиваються динамічніше, ніж це передбачено на законодавчому рівні. Законодавче регулювання державного зовнішнього боргу відсутнє, регулювання державного внутрішнього боргу вимагає вдосконалення.

Обслуговування державного внутрішнього боргу країни здійснюється Міністерством фрінансів України через банківську систему України шляхом проведення операцій з розміщення облігацій внутрішніх державних позик, інших цінних паперів, їх погашення і виплати доходу за ними у вигляді відсотків тощо. Обслуговування зовнішнього боргу реалізується в процесі виконання державного бюджету. Розрахунки належних до сплати сум з погашення та обслуговування зовнішнього боргу виконуються в доларах США. Перерахунок в національну валюту проводиться за прогнозним курсом валют до гривні. Оплату здійснює безпосередньо Державна казначейська служба України [3]. Величина державного боргу в національній частині зовнішньої заборгованості також залежить і від динаміки обмінного курсу.

Сукупність боргових зобов'язань держави містить також гарантований державою борг, що виникає внаслідок прийнятих на себе державою гарантій за зобов'язаннями третіх осіб, або прийняті на себе державою зобов'язання третіх осіб. Гарантований державою борг загальна сума боргових зобов'язань суб'єктів господарювання - резидентів України щодо повернення отриманих та непогашених станом на звітну дату кредитів (позик), виконання яких забезпечено державними гарантіями [1].
Відповідно до статті 18 Бюджетного кодексу України, загальний обсяг державного боргу та гарантованого державою боргу на кінець бюджетного періоду не може перевищувати $60 \%$ річного номінального обсягу валового внутрішнього продукту України. Це положення не застосовується у випадках: введення воєнного стану в Україні (в окремих її місцевостях); введення надзвичайного стану в Україні (в окремих її місцевостях) або проведення на території України антитерористичної операції. У разі очікуваного перевищення цієї граничної величини Кабінет Міністрів України зобов'язаний вжити заходи з приведення загального обсягу державного боргу та гарантованого державою боргу до встановлених вимог.

3 метою забезпечення дотримання граничних обсягів державного боргу та державних гарантій Боргове агентство України веде Реєстр державного боргу і гарантованого державою боргу, Реєстр державних гарантій. Інформація 3 відповідних реєстрів щомісячно публікується на офріційних сайтах Боргового агентства України та Міністерства фрінансів України. Реєстр державного боргу і гарантованого державою боргу $€$ інформаційною системою боргових і гарантійних зобов'язань держави, що включає умови кредитних договорів і випуску державних цінних паперів та умови надання державних гарантій, відомості про стан обслуговування і погашення державного боргу. Реєстр державних гарантій $\epsilon$ інсоормаційною системою, що містить відомості про надані протягом бюджетного періоду державні гарантії [1].

Державний i гарантований державою борг України з 2009 до 2021 рр. згідно даних МФУ[4], наведено у таблиці 1.

Державний і гарантований державою борг України, млн. грн.

Таблиця 1

\begin{tabular}{|c|c|c|c|c|}
\hline Дата & \multicolumn{2}{|c|}{ Загальний борг } & Зовнішній борг & Внутрішній борг \\
\hline на 31.12.2009 & 316884,6 & & 211751,7 & 105132,9 \\
\hline на 31.12.2010 & 432235,4 & $36,4 \%$ & 276745,6 & 155489,8 \\
\hline на 31.12.2011 & 473121,6 & $9,5 \%$ & 299413,9 & 173707,7 \\
\hline на 31.12.2012 & 515510,6 & $9,0 \%$ & 308999,8 & 206510,7 \\
\hline на 31.12.2013 & 584114,1 & $13,3 \%$ & 300025,4 & 284088,7 \\
\hline на 31.12.2014 & 1100564,0 & $88,4 \%$ & 611697,1 & 488866,9 \\
\hline на 31.12.2015 & 1572180,2 & $42,9 \%$ & 1042719,6 & 529460,6 \\
\hline на 31.12.2016 & 1929758,7 & $22,7 \%$ & 1240028,7 & 689730,0 \\
\hline на 31.12.2017 & 2141674,4 & $11,0 \%$ & 1374995,5 & 766678,9 \\
\hline на 31.12.2018 & 2168627,1 & $1,3 \%$ & 1397217,8 & 771409,3 \\
\hline на 31.12.2019 & 1998275,4 & $-7,9 \%$ & 1159221,6 & 839053,8 \\
\hline на 31.12.2020 & 2551935,6 & $27,7 \%$ & 1518934,8 & 1033000,8 \\
\hline на 28.02.2021 & 2552963,1 & $0,0 \%$ & 1489055,0 & 1063908,1 \\
\hline
\end{tabular}


Обсяг державного боргу в 2014 р. по зрівнянню 32013 р. значно зріс майже на 1,9\% 3 584,11 млрд. грн. до 1100,56 млрд. грн., а в 2015 р. по зрівнянню із попереднім роком збільшився ще на $1,4 \%$.

Відповідно даних [4], загальний борг України на кінець лютого 2021 р. в порівнянні 3 попереднім місяцем зменшився на 5,26 млрд. грн. (91,41 млрд. дол. США в еквіваленті в іноземній валюті), а саме на 0,2\%, в основному за рахунок зменшення гарантованого державою боргу на 5,23 млрд. грн. Протягом лютого валютний курс гривні по відношенню до долара США дещо укріпився, що призвело до зменшення державного зовнішнього боргу в гривневому еквіваленті на 11,20 млрд. грн. При цьому державний внутрішній борг збільшився на майже еквівалентну суму - 11,15 млрд. гривень. У доларовому еквіваленті державний борг збільшився на 0,75 млрд. дол. США. Структуру державного та гарантованого державою боргу за даними Міністерства фрінансів України на 28.02.2021 р. надано у таблиці 2.

Станом на 28 лютого 2021 р. частка державного боргу в порівнянні 3 груднем 2020 р. збільшилась $388,5 \%$ до 88,7\% на $0,2 \%$, а гарантованого державою боргу України зменшилась на майже еквівалентне значення $0,2 \%$ з $11,5 \%$ до $11,3 \%$.

Згідно із програмою управління державним боргом на 2021 р. витрати державного бюджету на 2021 р. $з$ погашення та обслуговування державного боргу заплановано відповідно до:

- грасріків платежів за вже існуючим державним боргом на момент складання проекту державного бюджету на 2021 р.;

- планових обсягів запозичень на 2021 р. на фрінансування державного бюджету; прогнозних відсоткових ставок та курсів валют;

- прогнозу обсягів витрат на управління державним боргом. Крім того, розрахунки платежів за державним боргом залежать як від інструмента запозичення (цінні папери, кредити, позики), так і від умов кредитування конкретних кредиторів (міжнародних фрінансових організацій, країн - партнерів та іноземних фрінансових установ) [5].
Помісячні платежі за державним внутрішнім й зовнішнім боргом у 2021 р. за діючими угодами станом на 01.04.2021 р. 3 урахуванням фрактично здійснених платежів, відповідно даним МФУ [4], наведені у таблиці 3.

Пікові платежі за державним внутрішнім боргом припадають на березень, травень та червень 2021 року, а саме 52,30; 43,31 та 62,19 млрд. грн., відповідно. Найбільші платежі за державним зовнішнім боргом припадають на вересень 2021 року у загальній сумі 81,36 млрд. грн., за комерційними позиками у сумі близько 57,71 млрд. грн. Прогнозні платежі за державним боргом на кінець 2021 р. складають 599,06 млрд. грн., причому за державним внутрішнім боргом 438,57 млрд. грн, а державним зовнішнім боргом - 160,49 млрд. грн, Частка видатків 3 обслуговування державного боргу у видатках загального фронду державного бюджету за 2021 рік орієнтовно становитиме 13,4\% - на рівні 2020 року.

Нерезиденти збільшили свій портфель українського державного боргу на 7,7\% або 7,3 млрд. грн за лютий 2021 р. Загальна частка нерезидентів серед власників ОВДП на кінець лютого становила 10,3\% або 102,7 млрд. грн.

Відповідно до Стратегії [2], основними заходами, що здійснюються в державі на протязі 2019-2022 років $€$ :

- збільшення частки державного боргу у національній валюті;

- залучення іноземних інвесторів до інвестування в облігації у національній валюті;

- подовження середнього строку до погашення державних цінних паперів і забезпечення рівномірного графріку погашення державного боргу;

- здійснення операцій з активного управління державним боргом 3 метою зменшення пікових навантажень на державний бюджет та стимулювання попиту на державні цінні папери;

- проведення роботи із забезпечення повноцінного доступу України на міжнародний ринок капіталу;

- подальше удосконалення політики управління державним боргом, в тому числі шляхом

\section{Структура державного та гарантованого державою боргу України}

Таблиця 2 на 28.02.2021 р., млн. грн.

\begin{tabular}{|c|c|c|c|c|c|c|}
\hline Назва боргу & \multicolumn{2}{|c|}{ Зовнішній } & \multicolumn{2}{c|}{ Внутрішній } & \multicolumn{2}{c|}{ Разом } \\
\hline Державний борг & 1237949,8 & $48,5 \%$ & 1025736,2 & $40,2 \%$ & 2263686,0 & $88,7 \%$ \\
\hline Гарантований борг & 251105,2 & $9,8 \%$ & 38171,9 & $1,5 \%$ & 289277,1 & $11,3 \%$ \\
\hline Сукупний борг & 1489055,0 & $58,3 \%$ & 1063908,1 & $41,7 \%$ & 2552963,1 & $100,0 \%$ \\
\hline
\end{tabular}




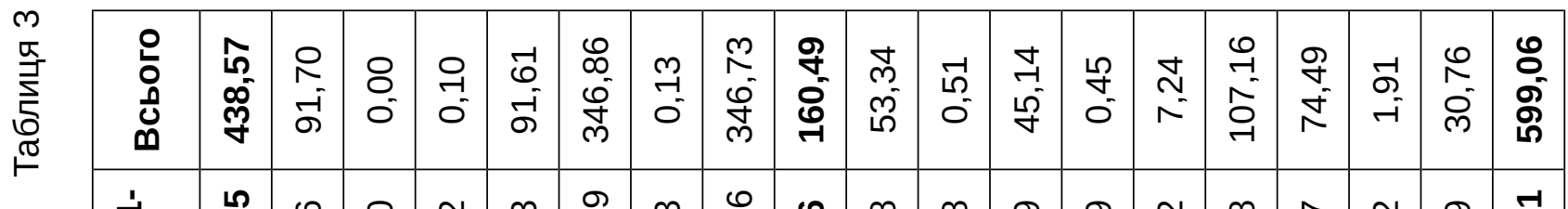

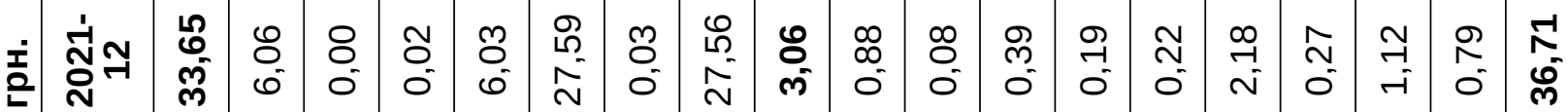
吉

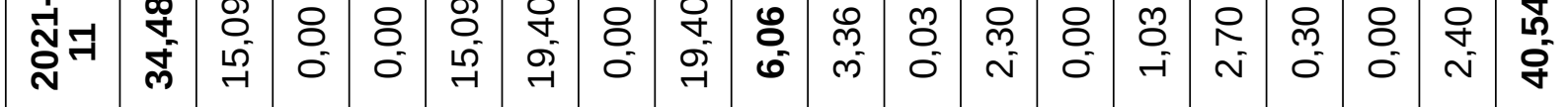
音

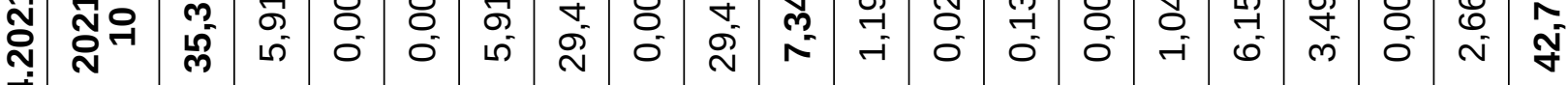

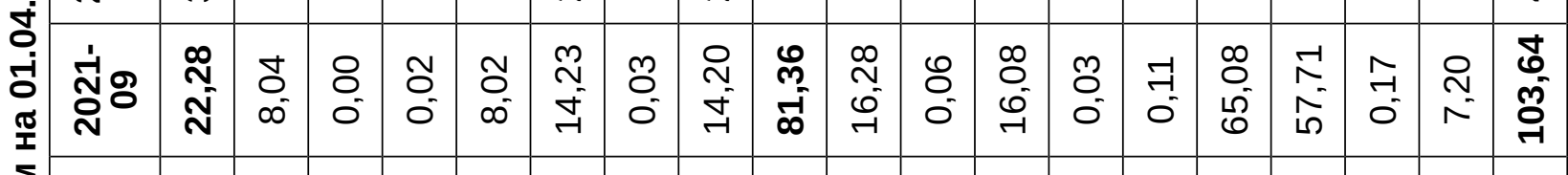
○

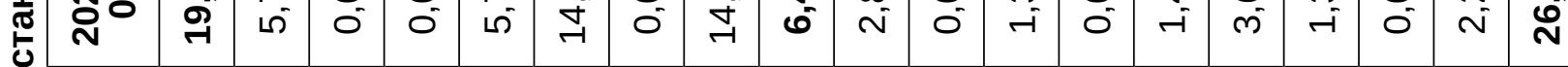

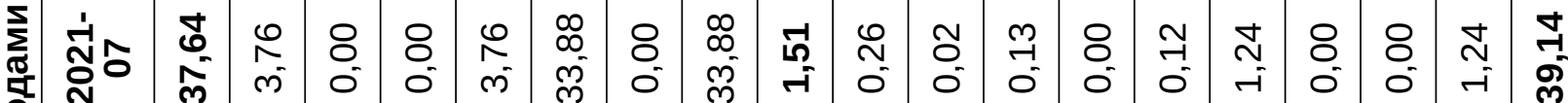

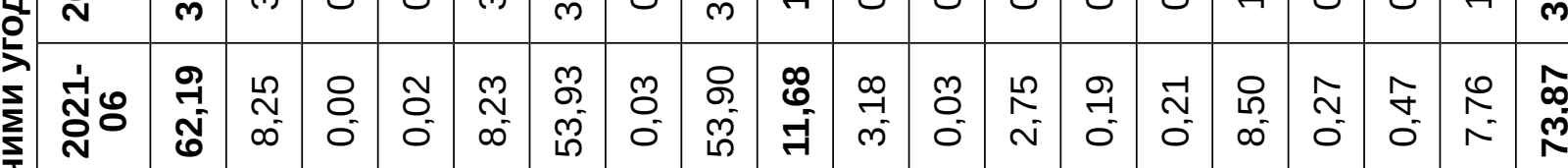

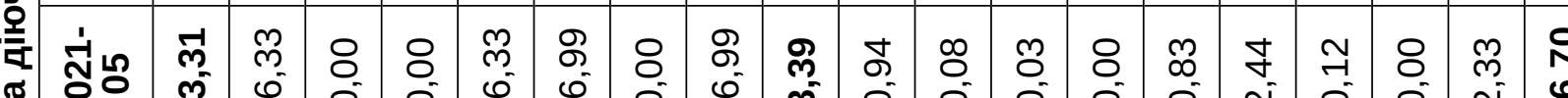
శ్ ․

守

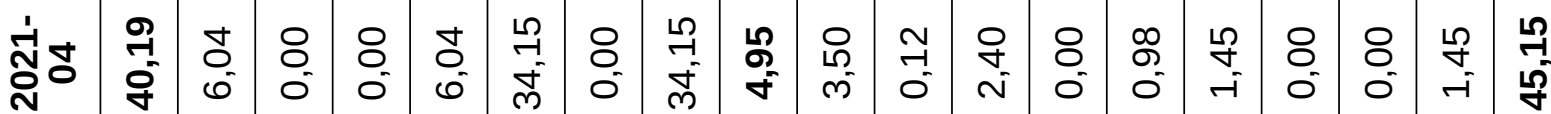
¿ : ส่ง

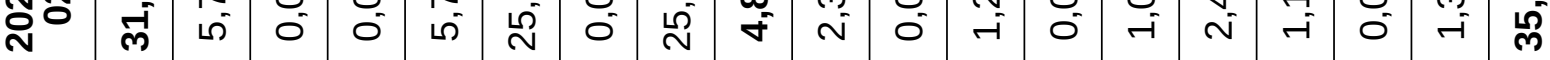

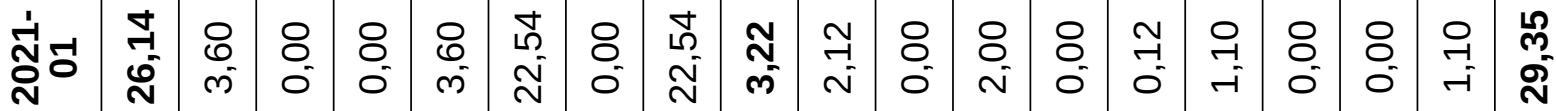

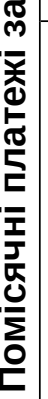
농

능
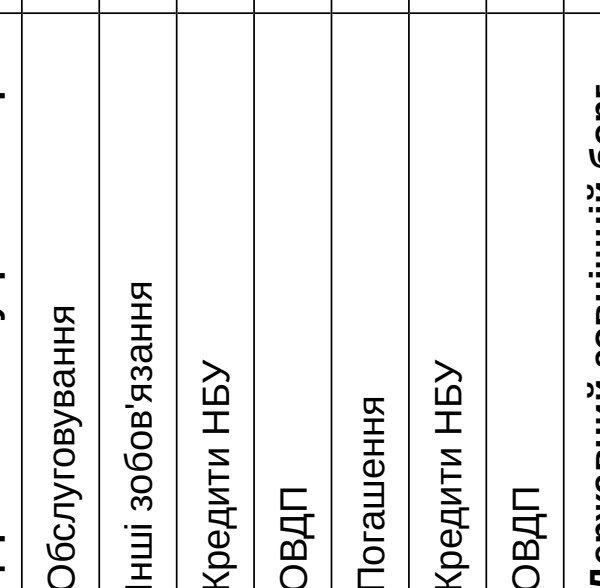

능
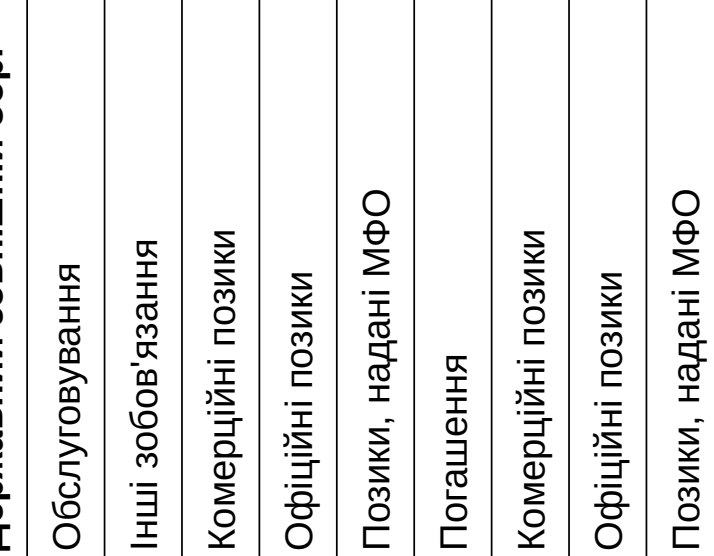
створення та ефрективного фрункціонування Агентства 3 управління державним боргом 3 використанням найкращих світових практик;

- розширення співпраці 3 міжнародними фрінансовими організаціями, зокрема Світовим банком, Міжнародним валютним фондом, Європейським банком реконструкції та розвитку, Європейським інвестиційним банком тощо.

Результатом впровадження Середньострокової стратегії управління державним боргом на 2019-2022 роки буде подальше збільшення прозорості політики управління державним боргом та сприяння підвищенню есрективності його управління.

На сучасному етапі перед економікою держави стоїть дві мети: розвивати фрінансовий ринок всередині країни і спрямовувати кошти на зменшення дефіциту в консолідованому бюджеті країни. При значному обсязі державного зовнішнього боргу відбувається зниження витрат на розвиток і розширення виробництва всередині країни, на соціальні потреби, в результаті, все позначається на рівні життя людей. Таким чином, відбувається уповільнення економічного зростання країни.

Державний зовнішній борг країни має як позитивний вплив на національну економіку країни, так і негативний. Позитивні наслідки полягають в наступному: великою вигодою для країни $€$ те, що існує можливість залучення до бюджету держави позикових коштів і збереження відносного розміру боргу; дефіцит бюджету в країні призводить до наростання обсягів державного боргу, а профріцит, навпаки, наділяє можливістю погашати борг. Якщо в країні спостерігається тривалий економічний ріст, то зростає дохідна частина бюджету, яка дозволяє сплачувати відсотки по боргу держави. Негативні наслідки полягають в наступному: при постійному збільшенні зовнішнього боргу держави, уряду доводиться стримувати капіталовкладення інвестицій в національне господарство країни; наростання зовнішніх запозичень веде до зниження своєї політичної незалежності тощо.

Висновки. Отже, від способів врегулювання боргової проблеми залежить рівень бюджетного забезпечення держави, стабільність ії національної валюти, а, звідси, фрінансова підтримка міжнародних фрінансових організацій. Необхідні пошуки шляхів вдосконалення механізмів управління та обслуговування державного боргу країни, посилення адміністративного контролю за фрінансовими потоками з боку держави, використання найкращих світових практик, а також залучення іноземних інвесторів до інвестування, що створить в майбутньому сприятливий інвестиційний клімат в Україні.

\section{СПИСОК ВИКОРИСТАНИХ ДЖЕРЕЛ:}

1. Бюджетний кодекс України. URL: https://zakon.rada.gov.ua/laws/show/2456-17 (дата звернення: 20.04.2021).

2. Про затвердження Середньострокової стратегії управління державним боргом на 2019-2022 рр., від 05.06.2019 p. № 473. URL: https://zakon.rada.gov.ua/laws/show/473-2019-\%D0\%BF\#Text (дата звернення: 22.04.2021).

3. Шелест О.Д. Державний борг України: механізм управління та обслуговування. Економіка і суспільство. 2017. № 8. С. 710-715.

4. Сайт Міністерства фрінансів України. URL: https://mof.gov.ua/uk/borgova-politika (дата звернення: 24.04.2021).

5. Програма управління державним боргом на 2021 р. Наказ Міністерства фрінансів України від 29 січня 2021 p. № 47. URL: https://mof.gov.ua/storage/files/\%D0\%9F\%D0\%A0\%D0\%9E\%D0\%93\%D0\%A0\%D0\%90\%D0 \%9C\%D0\%90\%20\%D1\%83\%D0\%B4\%D0\%B1\%202021.pdf (дата звернення: 25.04.2021).

\section{REFERENCES:}

1. Biudzhetnyi kodeks Ukrainy [Budget Code of Ukraine]. Available at: https://zakon.rada.gov.ua/laws/show/ 2456-17 (accessed 20 April 2021).

2. Pro zatverdzhennia Serednostrokovoi stratehii upravlinnia derzhavnym borhom na 2019-2022 r. [On approval of the Medium-Term Public Debt Management Strategy for 2019-2022], vid 05.06.2019 r. no. 473 (accessed 22 April 2021).

3. Shelest O.D. (2017) Derzhavnyi borh Ukrainy: mekhanizm upravlinnia ta obsluhovuvannia [Public debt of Ukraine: management and servicing mechanism]. Ekonomika i suspilstvo, no. 8, pp. 710-715.

4. Sait Ministerstva finansiv Ukrainy [Website of the Ministry of Finance of Ukraine]. Available at: https://mof.gov.ua/uk/borgova-politika (accessed 24 April 2021).

5. Prohrama upravlinnia derzhavnym borhom na 2021 r. [Public Debt Management Program for 2021]. Nakaz Ministerstva finansiv Ukrainy vid 29 sichnia 2021 r. no. 47. Available at: https://mof.gov.ua/storage/files/\%D0\%9F \%D0\%A0\%D0\%9E\%D0\%93\%D0\%A0\%D0\%90\%D0\%9C\%D0\%90\%20\%D1\%83\%D0\%B4\%D0\%B1\%202021.pdf (accessed 25 April 2021). 